\title{
MARKETING STRATEGY FOR INFORMAL WORKER GROUP IN CONSTRUCTION INDUSTRY IN INDONESIA
}

\author{
Kukuh Lukiyanto \\ Entrepreneurship Department, \\ Business and Communication Faculty, \\ Institute of Creative Technology Bina nusantara \\ Malang, Indonesia \\ e-mail: kukuhluky@yahoo.com \\ Maranatha Wijayaningtyas \\ Civil Engginering, \\ National Institute of Technology, \\ Malang, Indonesia
}

\begin{abstract}
The paper aims to identify foreman's strategies in marketing his/her group's service as well as analyzes how the foreman finds a job in construction project. Qualitative method with phenomenological approach was used to address the research's problem through a survey involving two project managers and four construction foremen. The paper provides the empirical insights about the marketing strategy applied by foreman as group leader in Indonesian construction industry. Foreman is regarded as an informal leader who has strong emotional and social ties with fellow workers. As the main liaison between management and labor, the foreman should be able to organize the work and labor to achieve project objectives. Management expects the foreman to be able to supply the needs of the labors of the construction projects, while the workers hope the foreman to be able to provide jobs for them regularly. Because of the chosen research approach, the research result may lack generalisability. In order to increase the generalisability, the researcher is encouraged to test the proposed hypothesis in the future research. The paper includes implications for the development of foremen's role in marketing strategy and for fulfiling the balance between project manager's and construction labours' rights. This paper fulfils how marketing strategy applied by foremen can fulfil the project manager's and the construction labours' rights.
\end{abstract}

Keywords: Foreman, construction workers, marketing strategy.

| Received November 2017 | Accepted December 2017 | Available online December 2017 | | DOI: http://dx.doi.org/10.18860/mec-j.vli1.4576

\section{INTRODUCTION}

Construction industry is one of the most challenging areas compared to other industries, particularly in terms of labour management and productivity (Khoramshahi et al., 2006). Human resources are very important in construction industry since the cost for labours is the highest of all other types of construction costs. The reason is that working hours for labours in carrying out their work affects more towards the management than the cost of materials and the cost of capital (Anonymus, 2015a). Due to such vital role, the selection of labours, including their quality and productivity, should be a major concern for whoever involves in construction industry. Better handling of labour in construction industry is considered crucial in order to fulfill the increasing demands (Soekiman et al. 2010).

In Indonesian construction industry, lower level workers such as carpenters and construction workers are generally not well-educated workers. For example, construction workers in Java were used to work in agricultural sector. Today, however, this has begun to shift, in which construction work has become a major job for some people who live in urban areas. (Anonymus, 2015b). Like agricultural workers, they also do not have any 
adequate formal education; their skills in construction area are limited to simple work that only require physical skills. Nevertheless, by learning few years from their seniors, some junior workers have succeeded to become such skilled workers as masons, carpenters, and steel workers.

These workers did not have any direct access to the company. At the same time, the company avoided dealing with the workers directly because the company did not want to be bound by the rules of employment towards workers with no adequate skill. The workers did not have any direct or formal contract with the construction company. The company fulfilled the needs of the workforce through a foreman as a leader of construction worker group. It is the foreman who prepared and signed the work contract provided by the company on behalf of the worker group. The workers recruitted by the foreman were based on their kinship, friendship, and personal relationships (Sjahrir, 1991). Due to the lack of relations in terms of education and skills, most construction workers become highly dependent on the foreman to get a job. They work from one project to another, following where the foreman goes for construction work.

In construction industry in Indonesia, the foreman is often regarded as the most important agent. Although there has been a shift from traditional construction method to modern one, the foreman is still considered as a key role for the success of a construction project. The relationship between management and labours is entrusted to the foreman, and the foreman is expected to manage the manpower to accomplish the project objectives. The foreman possesses full responsibility for the operational management of labour, labour productivity, labour costs, labour quality, and labour safety (Soemardi et al, 2011). Due to the important role of the foreman, the construction company handed over the foreman all things related to the required number and qualification of labours (Budiwibowo at all., 2009). The companies only need to provide job description, labour cost, desired quality and required time targets. The foreman himself/herself will execute the instructions given in operation. Based on this information, the foreman determines what kinds of skills are needed, as well as how many skilled and unskilled workers are needed.

\section{LITERATURE REVIEW}

\section{Worker Group Management as a Business}

The role of a foreman is not merely as an ordinary leader in her/his group. The foreman also acts as an entrepreneur. Another important role of the foreman is how he/she should manage her/his group as a company or a lucrative business for herself/himself and his/her group members. Business is a profit-oriented activity that involves buyers and sellers of goods or services to satisfy the community's needs and desires (Boone and Kurtz, 2002). Similarly, a group of worker led by a foreman, in management practices is a business because it is oriented to profit. A business that is managed in the form of a company constitutes an organization that involves a trade of goods, services, or both (Sullivan and Sheffherin, 2003). In this case, a group or an organization of construction worker is an informal or traditional organization which provide services. Worker groups of construction industries are formed based on common interests. In the respect of agreement, the group is formed based on a merely oral agreement without written agreement (Anonymus, 2015a). Because the deal is based only on verbal agreement, this group is usually called an informal group.

Like other informal groups in general, the group of construction workers will easily split due to simple matters. The absence of a written agreement makes the group members free to leave or to do their job any time they like. Nowadays, this kind of worker 
group become more responsive to the foreman's role as a leader in each of its activity. The foreman also acts as a group or a company owner, while the group members acts as employees salaried based on the work done. The foreman acts as an entrepreneur who sets up the things related to finance and human resources required. The is done by the foreman for the purpose of obtaining profit from the conntract cost varience and the cost he/she should pay. The advantage of being a foreman as an entrepreneur is that he/she rarely distribute profits to their employees as in previous days (Sjahrir, 1991).

A foreman should have managerial skill in order to be able to perform a role as a company leader. Planning, implementation, and evaluation must be arranged by the foremen, although most of them obtain this managerial skill not because they have learnt it from formal education but from experience. The foreman's success can be measured from several components which refer to his/her ability to complete the project based on the prescribed standards (Soeharto, 1997; Meredith \& Mantel, 1989; Gray \& Larson, 2006). The prescribed standards are: meeting specified deadlines; presenting work quality in line with the standards; being able to lower production costs using materials effectively; and maintaining work safety (Soemardi et al., 2011; Cheng, Ryan, \& Kelly, 2012). These abilities determine wheather or not a contractor would cooperate with the foreman in the future. This means that the ability to fulfil the standards by the foreman will enable him/her to still maintain his/her group. The foreman's managerial skills will determine whether he/she will get gains or losses. The losses, if any, are the responsibility of the foreman as an entrepreneur.

Based on the observation results, the unavailability of continued jobs was the main cause of the construction worker group unable to survive. It is contrast to the past where most construction workers who were originally agricultural workers spending their spare time for construction work (Sjahrir, 1991); therefore, they could still meet the needs of their family from agricultural production. This situation made them remain loyal to and stay in their group although there was not any construction work which they could do. The foreman could easily maintain her/his group in such situation.

Nowdays, cultural shift of construction workers has occured; construction work, which originally served as a side job, has become a main job. As a result, this cultural shift has made the loyalty of construction worker group decreased. (Anonymus, 2015b). In addition, the unavailability of work becomes a major problem for most construction workers because they have been dependent on the construction work. Therefore, when the construction work has been completed but there is not yet any new construction work for them for a long period of time, or more than two weeks, their economy becomes unstable. The wages they recieve as daily workers are not enough to be saved. In fact, their wages for one day are often enough for one day only; therefore, having no work for about two weeks has made construction workers unable to fulfill their familiy's needs. This factor made construction workers unable to survive in their group and encourage them to form a new group or join a group of other foremen instead.

\section{Foreman's Marketing Strategy}

As the leader of the group, the foreman must be responsible to the sustainability of his/her group. In other words, the sustainability of the group indicates the sustainability of the foreman's business as the leader of an informal enterprise. Due to main requirement must be fulfilled by the foremen is the continuity of the work, the problems faced by them is his/her ability to market his/her group. The efforts made by him/her to market his/her group is to convince the leader of the construction company to use the services of the foreman and of his/her group. In other words, the foreman must be able to convince the leader of the construction company that he/she and his/her group are able to work on the project in accordance to the requested specifications and demands. A business activity 
oriented to sustainable relationships with customers will be able to improve understanding on the customers' wishes and needs. According to Boone and Kurtz (2002), a company oriented to long-term relationships will develop opportunities to maintain competitive advantage through competative differentiation.

Berry (1995) also asserts that a company's success in maintaining relationship with it's customers was conducted by giving full attention to the quality and service. Maintaining quality in the long term will provide profitable experience for customers and will establish good relationship with them (Ojasalo, 2001). The quality of service provided by the company could establish business relationship among the companies. The relationship among companies both in economic and in behavioral dimensions are important aspects of the relationship (Wilkinson, 2001). The relationship between the company and customers based on the service quality can encourage the intention to establish a sustainable relationship. In the foreman's point of view, this relationship is based on service quality so it may create an intention to establish sustainable relationship between the customers and the foremen. The services provided by the foreman for the company is by implementating all instructions given properly. Because of it, the company as employer, gets convinced that the foreman's job will run well without any constraints from his/her labours.

For a foreman, maintaining the relationship with a lot of construction companies is crucial because when he/she and his/her group members have finished working on a project, they would continue to work on another project in another construction company in order to earn some money sustainably. Therefore, with an extensive relationship, when the foreman do not find any project in certain construction companies, he/she can as ask a job in other construction companies.

According to Huntley (2006), and Rajaobelina \& Bergeron (2009), a good relationship among companies had a positive impact on sales growth, future purchase intention, and loyalty. Thus, good relationship with construction companies is important for the foreman to maintain the sustainability of his/her worker group's job. In addition, a good relationship may occur because of the alignment of interest between the sellers and the customers. The company and the customers realized that the relationship will give some benefits for both parties (Bowen et al., 1989). Business relationship based on market orientation, service quality, and communication quality can contribute to the increase in sales, future purchase intention, and loyalty, thereby can establish an ongoing relationship. Maintaining the attitude, work quality, and service quality is a real effort of foreman to create sustainable relationship.

This phenomenon is interesting to study more deeply because with limited and low level of formal education, the foremen are able to perform their roles as marketers for their group. Although. the foremen have low educational and managerial skills - because they only gained them from experience- they are able to act as good marketers. With certain capabilities, they are able to maintain and make their group members remain loyal.

\section{METHODS}

The purpose of this study is to examine the strategies of foreman in marketing to get construction work continually for his/her group. The subject of this research was the foremen who succeeded in getting construction work continually. The measurement of foreman's success in this study was developed from the foreman's ability in maintaining his/heir group for more than five years on which the foreman gets construction work continually during that period.

Phenomenology qualitative method was used in this study to explore individual experiences of the foreman (Miles and Huberman, 2001), who has been successful in 
his/her marketing strategy. This study was conducted in East Java, Indonesia. Snow bowling method was used to locate the desired key informants. This method was used because the foremen know one another and they usually established a network and information exchange. The study involved four successful foremen as key informants. Survey and in-depth interviews were used to collect data regarding the foremen's marketing strategies. Triangulated data was used to check the truth of the collected information. Two project managers were interviewed in the study to provide some information regarding to the accuracy of information from the foreman. Data collection was carried out in two stages; firstly, stage for collecting theoretical data and secondly, stage for collecting primary data. The theoretical data were obtained from reference such as data on the foreman's scope of work, while the primary ones were collected from survey, which consist of the foremen's scope of work, assessment data from business partners, and marketing strategies used by the foremen.

The results will provide useful information as a general view of the foremen's marketing strategies in regards to how their marketing strategy skills can be formulated. The formulated marketing strategy can be further implemented as the basic effort to improve other foremen's skills. In addition, other parties can utilize these findings to provide training for other foremen to improve their marketing strategy skills.

\section{DISCUSSION}

The data collected from In-depth interviews were transcribed, grouped based on the theme, and then interpreted. The research results are described as the following:

\section{Labour Marketing Methods in Construction Industry}

Leadership is one of the aspects that influences the success of a project. Leadership in project management level contributes to project team and its success. In construction projects, contractor assigned foreman as a leader who is responsible for the implementation of construction work in the field. Construction company hires foreman as a temporary partner. Both Industry and government should recognize the strategic position of foremen in order to empower them as agents of change for construction workers.

Two project managers in this study agree that the foreman should ideally possess good working competence. The competence is often described as the ability of a person in certain fields such as verbal communication ability, presentation ability, technical knowledge, stress controlling, planning, and decision-making ability (Soemardi et al., 2009).

In general, the strategies they used in implementing marketing are based on habits which they have done for generations among them; the foreman looked for a new job when a previous one was or almost completed. This was conducted because a contractor could seldom provide continual job for the foreman (Anonymus, 2015b). By contacting their acquaintances or relations, the formen asked whether there was a new job for them.

The four key informants have the same opinion that most of the foreman relied on this way only, as one of them said: "Generally, it is like that, when the work is almost finished, to find other jobs, we will ask them to friends, acquaintances, or those who have ever followed us. From the beginning, the method is like that..."

Other traditional marketing patterns they usually used were by intermediary services. It was the intermediary who gave information regarding a project that required foreman and workers. In today's poor working culture situation of construction industry, many project managers become intermediaries for foreman to get a job and are certainly not free of charge, but in exchange for a certain fee. This condition is widely used by foremen 
who faces difficulties to get a job. Three of the four key informants asserted that they sometimes had to encounter the difficulties to get a job. They explained that sometimes these conditions could not be avoided. The project managers utilized them as a personal gain. They would give a job to foreman assuming that the foremen were prepared for giving certain amount of fee to the project managers. If the foreman rejected to do so, the job would be given to other foremen.

This kind of method is often used by the foremen with poor performance to look for a job. Without considering the amount of money they have to pay, they will give it as long as they can get the job. Certainly, this way creates unfair competition because they will be used by project managers who wish to get personal advantage, while the foreman have to lose their profits for having to pay the project managers.

Unlike those three foremen, a successful foreman usually gets a job offered by the project manager who has worked with them without any payment. With good working performance and good relationhip between the project manager and the foreman, the project manager often finds jobs for the foreman either in him/her own construction company or in other construction companies. The project manager does this so that the foreman will be loyal to him/her, so when the project manager needs her/him sometime later the foreman can directly join the project manager. A project manager who became an informant said:

"There are times we recommend them to follow managers of other projects. Their work quality is great, so we are sorry if they do not get a job after the project has been completed. Besides helping them, we also help other project managers to get a good worker. Actually, we also get advantage if we help them becuase they will be loyal to us. One time, when there is a new project, we can contact them and they will definitely be our priority. Furtheremore, it is hard to find a good foreman today."

This statement is also supported by a project document indicated by the informant that the manager conducting the projects employed the same foreman three times respectively. This shows that the project manager is satisfied with the employed foreman so he/she will employ the foreman again in the next project.

\section{Enhanching Skill as Marketing Efforts}

The fast development of construction technology requires all involved parties to learn and improve their skill continuously. As the responsible person for the construction workers, foreman is the first man who must follow the trend of the construction industry. $\mathrm{Her} / \mathrm{his}$ role is not merely to master new emerging technologies, but also to transform her/his ability to the workers. Foremen are people who deal directly with the construction company, so that the information would be given directly to the foreman. Therefore, the foremen have to explain what jobs must be accomplished to their group members.

Cultural shift of the construction workers makes the work in the construction industry as a steady job, making the group members have low loyalty to a foreman (Anonymus, 2015b). The frequent transfer of workers from one foreman to another results in the decrease of the learning opportunities for workers. If a worker is loyal to the foreman, s/he will be taught a new job by the foreman. In this case, the foreman should be ready with good quality human resources, so when the construction company needs workers with specific skills, the foreman can privide them sooner. Having workers with good skills is an advantage for the foreman. In modern construction management system, workers with specialized skills who do not only master the work in the field but also have a certificate from certain institutions are highly needed (Adhi \& Ni'am, 2012). It can be said that good 
worker skills may be used as a marketing tool for the foreman. A key informant describes it as the following:

"We have to teach the workers constantly, if they have good abilities we will be well-known as a good foreman; the company will see us as people who can provide qualified workers. By doing so, without any marketing, people will continuely look for us."

Four key informants said the same thing, mastery of new technologies and enhancing skills of workers must be carried out in the era of modern construction management. Some pictures taken during the field observations also show the learning process of workers and foremen toward new technology. One picture illustrates a foreman who was studying how to use paint thickness gauges, which is taught by the project supervisor. Another picture illustrates how workers measure paint thickness after been taught by the foreman. Thus, it can be trusted that the information saying that the mastery of technology have become important factors for the workers.

More or less work offered by the company manager is highly dependent on worker group's ability under the leadership of the foreman in fullfiling the demands of technology and skill. From the explanation of the four key informants it can be concluded that the company nowadays does not simply get foreman or workers, but rather choose a foreman with workers who have wide range of skills as needed to avoid more than one foreman in one project. The company expects employees with various skills needed can be provided by the foreman. As described by one key informant, in order to get a job easier he/she had to strengthen her/his work group with various skills such as skill in construction, in welding, in electricity, and other skills needed by the construction company. One key informant explains as follows:

"We must own workers with a various expertise. Nowadays, it is not enough to have only a builder, we must also have a welder. A lot of buldings now are constructed from iron or steel, so if you do not have any welder, the companies should provide their own; otherwise, the job cannot be done parallelly and it will be done very slowly because there is more than one foreman in the project provided by the construction company. Similar case would happen if you do not have any electrician".

In the situation where workers have low loyalty to the foreman, the foreman will encounter difficultty in getting workers with a wide range of skills. Worker turnover often result in the lack of workers with specific skills when needed. To overcome this problem, three of the four informants state that they must master a wide range of expertise, so the job will not be interrupted when it is left by workers with specific skills. They equip themselves to learn all sorts of skills required in the project. The three key informants state that they are able to master the skill of building, welding, and electricity. They should master these skills so they can understand if there is an explanation or request from the job-related companies. By doing so, the foreman will not make mistake in giving instructions to the workers. In addition, the job will not be stopped if it is left by a worker with specific skills needed. The foreman can also work on his own while teaching other workers.

One key informant is in contrast to the other three. He masters only one skill, that is building skill. However, he reliazes that a worker should master various skills. Age factor makes him difficult to learn other skills. Feeling old, he tries to meet the workforce with special skills needed to seek as much information about them. In addition, he also maintains good relationships with workers outside the group so that when he needs, he 
can straight away ask them to join him. This informant agrees that the foreman should master various skills in order to explain technical jobs to the workers.

As the informal leader of a group of construction workers, the foreman encounters difficulty if he/she should continue to follow the development of modern construction management. The rapid changes in technology oblige them to continue to learn something new, while the foreman's role is not only in technical terms but also in management matter. This condition justifies the opinion of Pendleton (2011) who said that the difficulty of integrating informal leadership pattern to a formal system in modern construction industry will result in the delay of the completion of construction projects. Therefore, there must be a strong consideration for the management company to choose a foreman in order to reach the target.

\section{Providing Satisfaction to the Employers}

In general, the culture of Indonesian construction workers is the same as other indonesian workers. Nowdays, Indonesian workers tend to show their transactional attitudes (Ratam \& Mazzarol, 2004; Justice et al., 2013). At the same time, transactional culture of the construction workers will affect the performance of the foremen. In the past, the workers already knew what to do without waiting for orders; today, however, the workers are always waiting for orders what to do. Therefore, executing tight control over the workers to reach the target is necessary. The performance of the foremen will strongly be influenced by the workers' transactional attitudes, but the transformational leadership style --which has been widely performed in construction industries in the developing countries-- is difficult to implement (Ofori \& Toor; 2012). Based on this fact, to achieve maximum results, supervision should be improved.

The transactional attitudes shift the functional structural culture of Indonesian community, especially among the Javanese (Daryono, 2006). The Javanese workers know well what to work on based on his/her each capacity and performs his/her tasks and responsibilities without any command and control. These transactional attitudes are good compromises to anticipate the economic demands and the business interests that have greately been affected by the capitalist culture. Nevertheless, when the transactional attitudes are performed with responsibility by both parties (the foremen and the workers), these will encourage them to achieve their respective goals without harming each other. The transactional attitudes can motivate the workers to work better and to improve the effectiveness of the organization as a whole (Manzoor, 2012).

Two of the key informants have transactional understanding as the price that he/she has to offer and should be followed by others, as shown in the following explanation:

"The workers often say, if not paid on demand, they do not want to work, but I also have a requirement for them, they should be able to achieve the target. If they cannot reach the target, their salary will be reduced based on their abilities. I think this is fair enough, it is fine for the workers to ask for higher salaries, but their performance should also be fine".

Despite the fact that not all workers understand transaction as a compromise, the foremen still use this attitude to avoid losses. Personal approach is made to give sense to the workers that the situation faced by the foremen is not always beneficial. This opinion is justified by the informant (project manager) who said that most workers now are unruly; they want to win by themselves; even they do not want to do heavy work and wish to work for short time, but ask for higher wages. Elder workers, however, do not behave like that. Manners inherited from cultural and ancestral heritage are still attached to them so that embarrassment and Tepo Sliro (tolerance) are still held in the high esteem. 
Despite facing this attitude, the foreman must be able to fulfill the demands of the company according to the agreement. The situation is not easy, but the four informants have the same view that the challenge they encounter is to give satisfaction to the employer. At the same time, the employees will usually get satisfied if they have recieved their wages as they requested to the employer; The satisfaction of the two parties will guarant the continuity of the work and will strengthen good relationship among group members. Nevertheless, disharmonious relationships among the group members are often unavoidable due to the competition among the workers or the envy of one another. In facing this situation, as the leader of the group, the foreman should be able to overcome this problem by treating the workers equally, without discrimination. The difficulty to organize the wokers does not mean that the foremen have to make the employers disappointed, if so, in the future, it will be difficult for them to find a job.

The employer's demands that refers to the three benchmarks of success in construction management are quality, cost, and time. These benchmarks of success must be fulfilled by the foreman who depends heavily on the workers performance. Hence, the foreman must be able to control the workers to be directed to fulfill all three. Quality depends on labour's skill and cost is affected by the worker's ability to use raw materials efficiently. Project timeline depends on the workers' performance and the methods used by the workers. It is clearly visible that the foreman should have positive influence on workers. Employee's satisfaction becomes the main purpose of the foreman because it will futher affect the employer's satisfaction, as they say:

"As leaders, we must serve the workers and try to make them satisfied. Their influence will be long and interrelated. If the workers are satisfied, they will work well and obey what we assign. Some do not even need to be asked because they already know what to do. So, our work will be good and in line with the company's expectations. If the companies are satisfied with our performance, we will be invited again when a new project is available".

The above description shows that one of the key marketing strategies of the foreman is to give satisfaction to the employer. Employer's satisfaction can be obtained if the workers are satisfied and happy. Employer's satisfaction will result in potentially new job offered by the company. New job implies to continuity of work, where the continuity of employment may affect worker's satisfaction. Keeping the satisfaction of all parties must be carried out by the foreman as an effort to market her/his group. The satisfaction of one party will affect other party's satisfaction, the satisfaction of all parties means the opportunity to get new job in the future.

\section{Maintaining Relationship}

Construction companies do not always get a job continuously. The completion of a project may not necessarily be connected to other projects. A construction company may get a new job when the project has not been completed, so the company may use the foreman's service that is different from previous project. Such conditions require the foreman to have extensive relationships with construction companies.

Contact was made in the form of communicating each other and not just limited to the employment's purposes. Under certain conditions, the foreman and the company (represented by the project managers) helped each other. When the company was still in the bidding process or got a job, they usually had to offer price to employers. In preparing the price offer, some companies usually involved foreman. Labour cost components were initially confirmed to the foreman regarding the price given was the right one. From this process, if the project could be obtained, the labour affairs would be offered to the foreman. Hence, the foreman's role in this case was crucial and became a 
potential resource for the construction company. This potential was used by the companies to bid on a project. Two informants (project managers) justified this description as one of the them said:

"Before bidding or participating in a tender project, we should be sure to have manpower or foreman who is ready for help. We should already know his/her qualifications and abilities; otherwise, it will be difficult if the bidding has been won, but we do not have any workers yet. The delay in completion of the project will occure and consequently we will be punished by employer. "

In addition, sometimes the company or project managers tried to find jobs for a good foreman and regularly worked with him/her. As discussed previously, in order to maintain a good foreman, project managers would try to find jobs for them when his/her company does not have any projects available for the foreman. This effort was done so that the companies did not lose their potential labour force that could be relied upon. A good foreman usually understands the reciprocation. Becuase the foreman has been accepted then he felt indebted to the project manager. In paying the indebtedness, the foreman should prepare himself any time to work with the project manager. Four key informants agree to this statement. They regard this eastern culture as explained by one of them as follows:

"We must be ready, if we are called upon any time, eastern tradition teaches us not to forget the help of others. If we have been helped by others, then we must also help them if needed. Nowadays, to find good workers is not easy so that it is a pity of the project manager if he /she cannot find good workers; his achievements in the company will get bad. As people who hold the oriental customs, we must support the people who have helped us."

Maintaining a relationship can be done in simple ways, such as visiting the company, making a call or sending a short message to project manager asking for news. These ways can be reminders of the foreman's presence. By doing so, the project manager will directly contact the foreman if there is a job to offer, because intimate relationship has already been established. All key informants agree that those who need a job, should be proactive in keeping in touch with the company or with the project manager. The following explanation describes the importance of the relationship:

"The relationship must be maintained, we must be proactive. Project manager have so many duties or tasks that he/she might forget us when there is a job available. By keeping in touch with the project manager, he/she will always remember us, and will give us priority if a job is vailable. We do not need to constantly come up, we may just making a call or sending a short message. We need the work, and have many competitors, so we have to be proactive."

It is clear that maintaining relationship is a necessity for the foreman. Communicating with many companies allows them to get many job opportunities and maintain work continuity. From marketing perspective, it can be regarded as foreman's marketing strategy. What the foreman does support Parmigiani's statement (2007), that establishing good relationship is beneficial to the company and an opportunity to learn, open new markets and innovative services in order to increase business transaction. 


\section{CONCLUSION}

The rapid development of construction industry in Indonesia leads to many new technologies. Management demands of the modern construction which refers to the concept of Maredith \& Mantel (1989), who state that to achieve goals, the construction company should use resources effectively by implementing action planning, organizing, actuating, and controlling. In fact, the construction project management in Indonesia still use traditional management in lower workforce management level. The existence of a foreman as the informal leader of the worker group is still a main choice for construction companies to fulfill workforce's needs.

Foreman has two roles, as an informal leader of the worker group and as an informal company leader. As an informal company leader, the foreman should be able to market his/her group to get jobs continuously. Job continuity can guarantee the existence of worker group to remain solid and loyal. In order to maintain job continuity, the foreman should create an effective marketing strategy.

To be effective, marketing must consider what action should be done to face the situation of the construction industry in Indonesia today. The results of the analysis and data processing related to the foreman's marketing strategies are as follows:

Table 1 Marketing Strategy for Informal Worker Group

\begin{tabular}{lll}
\hline \multicolumn{1}{c}{ Activity } & \multicolumn{1}{c}{ Aim } & \multicolumn{1}{c}{ Object } \\
\hline Improving skills & - Fulfilling the demands of the project & - Foreman / herself \\
& - Increasing profits & - Workers \\
& - Marketing strategy & \\
\hline Giving satisfaction & - Improving the performance & - Workers \\
& - Fulfilling the demands of the project & - Employer \\
& - Marketing strategy & \\
\hline Keeping the relationship & - Marketing strategy & - Employer
\end{tabular}

Table 1 shows that the marketing strategy of the informal worker group represented by the foreman can be done by improving skills. The efforts of improving skills should be done for himself/herself and for his/her workers. Better skills can increase the competitiveness of worker group of construction. The increased competitiveness may bring higher bargaining power and guarantee work continuity.

The second marketing strategy of the informal worker groups is to satisfy the related parties. Satisfaction accepted by the workers can improve their performance. When workers' performance improve, they will fulfill the project demands. Employer's satisfaction can be achieved if the worker group fulfills all the project demands. Employer's satisfaction may affect re-employment by the employer. Therefore, keeping the satisfaction is the marketing strategy of the foreman.

The third marketing strategy undertaken by the foreman is to maintain the relationship with the employer. Communication and effort to help each other is a form of keeping in touch. Building intensive relationship will allow certain foreman as the main priority for the project manager in determining the first choice who will be invited to work in a next construction project.

Based on the above description, the results of this study can be summarized that the marketing strategies of the informal worker groups in construction industry in Indonesia represented by the foremen are improving skill, giving satisfaction to workers and employers, as well as maintaining a good relationship with the employer.

The results of this research do not measure how far the effect of the three marketing strategy components nor the greatest impact on the success of foreman's marketing strategies. Therefore, it is necessary to conduct a quantitative research in order to measure 
the effect of each component. In addition, many other influences on foreman's marketing strategy that has not been analyzed, such as cultural, economic, and political standpoint.

\section{REFERENCES}

Anonymus. 2015a. Construction Workers Phenomenon and Java Traditional Leadership of Modern Construction Management in Indonesia. International Journal of Business and Management Invention, Vol. 4 issue 2, 09-13. Retrieved from http://www.ijbmi.org/papers/Vol(4)2/Version-1/B042109013.pdf.

Anonymus. 2015b. Cultural Shifting of Construction Workers and the Effect on Construction Project Management in East Java. Australian Journal of Basic and Applied Sciences, 9 (11), 191-197. Retrieved from http://ajbasweb.com/old/ajbas/2015/May/191-197.pdf

Berry Leonard L., 1995. Relationship marketing of services - Growing interest, emerging perspectives. Journal of the Academy of Marketing Science. 23 (4), pp.236-45. doi:10.1177/009207039502300402.

Bowen, D., Siehl, C., \& Schneider, B., 1989. A Framework for Analyzing Customer Service Orientations in Manufacturing. The Academy of Management Review, 14(1), pp. 75-95. Retrieved from http://www.jstor.org/stable/258192.

Budiwibowo, A., Trigunarsyah, B., Abidin, I. S., \& Soeparto, H. G., 2009. Competitiveness of the Indonesian construction industry. Journal of Construction in Developing Countries, 14 (1), 51-68. Retrieved from http://web.usm.my/jcdc/vol14_1 2009/4_Agung\%20(p.51-68).pdf

Boone, Louis E., \& Kurtz, David L., 2011. Contemporary business. (14 ${ }^{\text {th }}$ ed.). New York: Wiley Publishers.

Cheng, E., W. L., Ryan, N. \& Kelly, S., 2012. Exploring the perceived influence of safety management practices on project performance in the construction industry. Safety Science 50 (2012) 363-369. doi.org/10.1016/j.ssci.2011.09.016.

Daryono., 2006. Etos Dagang Jawa: Studi Terhadap Pemikiran Sri Mangkunegara IV. Master Thesis. Postgraduate Program of the Institut Agama Islam Negeri Walisongo, Semarang.

Gray, C. F. \& Larson, E. W., 2006. Project Management: The managerial process (3th ed.). New York: The Mac Grow Hill Companies, Inc.

Huntley J. K., 2006. Conceptualization and measurement of relationship quality: Linking relationship quality to actual sales and recommendation intention. Industrial Marketing Management, Vol. 35, 703-714. doi.org/10.1016/j.indmarman.2005.05.011.

Justice, O.B., Adison, R., Ade, F. S., 2013. Effective leadership in the eyes of followers: an empirical study in Indonesia. Journal of Transformative Entrepreneurship, Vol. 1, Issue 1, 14-24.

Khoramshahi, F., Dehghan, R., \& Mortaheb, M. M., 2006. Factors Influencing Construction Productivity. The 10th East Asia-Pacific Conference on Structural Engineering and Construction, Bangkok, Thailand, August 3-5, 2006.

Manzoor, Q. A., 2012. Impact of Employees Motivation on Organizational Effectiveness.

Business Management and Strategy, Vol 3 no 1, 36-44. DOI: https://doi.org/10.5296/ bms.v3i1.904.

Meredith, J. R. \& Mantel, S.J., 1989. Project Management: A Managerial Approach, (2th ed.). Canada: John Wiley \& Sons, Inc. 
Miles, M., B. \& Huberman, A., M., 2001. An Expanded Sourcebook: Qualytative Data Analysis. London: Sage Publication.

Ofori, G., \& Toor, S. R., 2012. Leadership and Construction Industry Development in Developing Countries. Journal of Construction in Developing Countries, 1, 1-21. Retrieved from http://web.usm.my/jcdc/vol17_s1_2012/Art\%201_jcdc17-s1.pdf.

Ojasalo, J., 2001. Managing customer expectations in professional services. Managing Service Quality, Vol. 11 No. 3, 200-212. Doi: http://dx.doi.org/10.1108/ 09604520110391379.

Parmigiani, A., 2007. Why do firms both make and buy? An investigation of concurrent sourcing. Strategic Management Journal, Vol. 28, No. 3, 285-311. Doi: 10.1002/smj.580

Pendleton, G. B. J., 2011. The Informal Leader's Role on Construction Sites: A comparative analysis of formal and informal leadership structures within the construction industry. Phd. Thesis, The Faculty of the Virginia Polytechnic Institute and State University, Master of Science In Building/Construction Science and Management. Retrieved from http://hdl.handle.net/10919/76996.

Rajaobelina, Lova., \& Bergeron, Jasmin., 2009. Antecedents and consequences of buyer-seller relationship quality in the financial services industry. International Journal of Bank Marketing, Vol. 27, Issue 5, 359 - 380. Doi: http://dx.doi.org/ 10.1108/02652320910979889.

Ratam, D., A., \& Mazzarol., T., 2004. A Model of Leadership, Strategy and Company Structure in Innovative Indonesian SME. Paper presented at Australia and New Zealand Academy of Management (ANZAM). Annual Conference 8-11 December 2004, Dunedin, New Zealand. Retrieved from http://researchrepository.uwa.edu.au/ en/publications/a-model-of-leadership-strategy-andcompany-structure-in-innovative-indonesian-sme(cec13082-c33b-4467-8c69f6f300aa5399).html

Sjahrir, K., 1991. Workers in the Indonesian Construction Industry. Proquest Dissertations and Theses; ProQuest Dissertations \& Theses Full Text.

Soeharto, I., 1997. Project Management: From Concept to Operation (Manajemen Proyek : Dari Konseptual Sampai Operasional), (3rd ed.). Jakarta: Erlangga.

Soekiman, A., Pribadi, K.S., Soemardi, B.W., \& Wirahadikusumah, R.D. (2011). Factors Relating to Labour Productivity Affecting the Projects Schedule Performance in Indonesia. ScienceDirect, Procedia Engineering, Vol. 14, p. 865-873. https://doi.org/ 10.1016/j.proeng.2011.07.110.

Soemardi, B. W., Soenaryo, I., \& Wahyudi, E., 2011. The Role and Function of Mandor in Construction Project Organization in Indonesia. SienceDirect, Procedia Engineering, Vol. 14, 859-864. https://doi.org/10.1016/i.proeng.2011.07.109.

Soemardi, B. W., Soenaryo, I., Budiman, A., \& Soekiman, A., 2009. Assesing the Role and Competence of Mandor in Indonesia Construction Industry. Second International Conference on Contruction in Developing Country (ICCIDC-II), August 3-5, 2010, CairoEgypt.

Sullivan,, Arthur., \& Sheffrin, Steven M., 2003. Economics: Principles in Action. New Jersey: Pearson Prentice Hall. Retrived from https://www.scribd.com/doc/55444148/ Economics-Principles-in-Action-Arthur-Sullivan-Steven-M-Sheffrin. 
Wilkinson, I., 2001. A history of network and channels thinking in marketing in the 20th century. Australasian Marketing Journal, Vol. 9 (2), 23-52. https://doi.org/10.1016/ S1441-3582(01)70174-7. 